\title{
EFFECTS OF PSYCHOLOGICAL INTERVENTION ON REHABILITATION OUTCOMES IN PATIENTS WITH SPINAL CORD INJURY; A SYSTEMATIC REVIEW
}

Muhammad Ayaz ${ }^{1}$, Syeda Ayman Zaidi ${ }^{1}$, Muhammad Hamza Khan ${ }^{1}$, Aatik Arsh ${ }^{1}$

Submitted: December 05, 2020
Accepted: June 04, 2021
Published: June 30, 2021
Authors' Affiliation
${ }^{1}$ Institute of Physical Medicine
and Rehabilitation Khyber
Medical University, Peshawar

Corresponding Author

\section{Dr. Aatik Arsh (PT)}

Institute of Physical Medicine and Rehabilitation Khyber Medical University, Peshawar Email:

aatikarshkmu@yahoo.com

\section{ABSTRACT}

Introduction: Psychological issues are common in patients with spinal cord injury (SCI) which negatively affects rehabilitation outcomes. Therefore, early psychological interventions are as important as physical rehabilitation. The aim of the study was to systematically review literature regarding the effects of psychological interventions on rehabilitation outcomes in patients with SCI.

Material \& Methods: A systematic review was conducted according to the PRISMA guidelines. Literature was searched in PubMed and PEDro databases. Articles published in English language from earliest record to August 2020 were searched. Observational and interventional studies which assessed effects of different psychological interventions on rehabilitation outcomes in patients with SCI were included. Review articles, editorials, short communications and conference papers were excluded. Quality assessment of the interventional studies was assessed using PEDro scale while methodological quality of the observational studies was carried out using NIH quality assessment tools.

Results: On the basis of eligibility criteria, 13 studies were included. Out of the total studies, 11 were observational studies and the remaining 2 were interventional studies. The included studies reported that psychological interventions improve rehabilitation outcomes such as functional independence, community participation and quality of life.

Conclusion: Psychological treatment is an effective complement to physical rehabilitation interventions to improve functional status of patients with SCI.

Key Words: Psychological interventions, Rehabilitation, Spinal cord injury.

The authors declared no conflict of interest and agreed to be accountable for all aspects of the work in ensuring that questions related to the accuracy or integrity of any part of the work are appropriately investigated and resolved. All authors contributed substantially to the planning of research, question designing, data collection, data analysis and write-up of this review article.

This review article may be cited as: Ayaz A, Zaidi SA, Khan MH, Arsh A. Effects of psychological intervention on rehabilitation outcomes in patients with spinal cord injury; a systematic review. Rehman J Health Sci. 2021;3(1). 2-9

\section{INTRODUCTION}

Spinal Cord Injury (SCI) is a less occurring condition with overwhelming long-terms adverse effects on an individual's life. Reduced mobility and functional dependence can lead to physical and psychological complications. ${ }^{1} \mathrm{SCI}$ is a threat to the patient's mental and physical health and have negative influences on a person's social wellbeing. ${ }^{2}$ Psychosocial issues have become more prominent in the last few decades and the range and nature of associated negative psychological effects needs to be carefully examined. ${ }^{3}$

The array of physical impairments associated with SCI increase the risk of developing anxiety and depression in patients with SCI. Research suggests that anxiety have been observed in $23-35 \%$ of SCI individuals and elevated depression symptoms in $35-38 \%$ people. ${ }^{4}$ These psychological issues have a huge impact on rehabilitation outcomes in patients with SCI. Studies reported that psychological factors such as mood, coping strategy and cognition are some of the contributing factors when justifying variances in functional independence. ${ }^{5}$

Recovery from SCI requires an organized rehabilitation plan and implementation of psychological treatments which is inevitable as developing emotional wellbeing is the key to rehabilitation. ${ }^{6}$ Early detection of psychological issues are important and according to research, less mood related issues were detected in patients who were diagnosed and treated earlier through prophylactic treatment. Studies suggest that cognitive behavior therapy during the rehabilitation phase not only improves depression and anxiety in the individuals but also refines relationship, social adjustment and decrease hospital readmissions. ${ }^{7}$

Recently conducted reviews shows positive psychological outcomes in patients with SCI when given psychological intervention along with conventional rehabilitation. Previous reviews on psychological 
interventions for patients with SCI reported promising results, ${ }^{8,} 9$ however, none of these reviews assessed effects of psychological interventions on rehabilitation outcomes. Despite the fact that it is commonly presumed that mental health can affect rehabilitation outcomes, nevertheless, there is limited evidence to support this assumption in patients with SCI. The objective of current study was to systematically review the available literature which reported effects of psychological interventions on rehabilitation outcomes in patients with SCI.

\section{MATERIAL AND METHODS}

A systematic review was conducted in accordance with PRISMA guidelines. Literature was conducted using PubMed and PEDro databases. Within these databases, the following terminologies were searched: ("psychological intervention" OR "psychotherapy" OR "psychosocial treatment" OR "psychological education" OR "psychological services" OR "cognitive behavior therapy" OR "cognitive behavior treatment") AND ("rehabilitation outcomes" OR " psychological rehabilitation" OR "recovery" OR "rehabilitative process" OR "coping strategy" OR "quality of life" OR "length of stay" OR "functional independence" OR "community participation") AND ("spinal cord injury" OR "spinal cord damage" OR "ischemia" OR "paraplegia" OR "quadriplegia" OR "tetraplegia"). Truncations were used when suitable. Other search engines like Google scholar was also searched. We also searched the reference lists of searched articles to find other supplementary relevant studies that have been missed from databases search results.

Articles published in English language from earliest record to August 2020 were searched. Observational and interventional studies which assessed effects of different psychological interventions on rehabilitation outcomes in patients with SCI were included. We included studies in which participants were given some psychological intervention and effects of these interventions were observed in rehabilitation outcomes including functional independence, coping strategies and quality of life. Review articles, editorials, short communications and conference papers were excluded.

All reviewers used inclusion criteria to determine the potentially relevant studies for selection. We independently filtered titles, abstracts and full text articles and rejected the irrelevant ones. We reported and settled disagreements by discussion. Three reviewers (AZ, MA, MH) assessed the titles of potentially relevant studies. The abstracts and full text articles were further screened. After duplicate removal, all potential studies were downloaded and reviewed independently by all three authors to ensure accuracy. Relevant data were selected and extracted on the bases of participants' characteristics, interventions given and outcomes. The following variables were extracted from the included article: study, year of publication, country, study design, target population, psychological intervention, outcome measures, rehabilitation outcomes and additional findings. PEDro scale was used for the quality assessment of the interventional studies and methodological quality of observational studies was assessed using NIH quality assessment tool.

\section{RESULTS}

The initial search identified 264 articles and 5 studies were identified through additional sources. After the removal of duplicates, the reviewers were left with 214 studies. Titles and abstracts of these articles were screened out and 181 were excluded because they were either not in the English language or were reviews articles or used interventions other than psychotherapy, or had participants with physical illness or disabilities other than SCI. A total of 38 full-text articles were evaluated and screened for eligibility. Out of the 38 articles, 25 were excluded because they did not report effects of psychological interventions on rehabilitation outcomes. Finally, 13 articles were selected for this review (Figure 1).

The studies were published in the years 1997-2017. Out of total studies, 11 were observational studies and the remaining 2 were interventional studies. The methodological quality of these studies was assessed and reported by NIH assessment tool $(n=11)$, (Table 1$)$ and PEDro scale ( $\mathrm{n}=2$ ) (Table 2).

Mainly cognitive behavior training was adopted as the psychological approach in most of the studies $(n=5)$. Along with it, psycho-education and social skills guidance $(n=5)$ were also implemented in some of the intervention strategies of the reviewed studies. Marked improvements were observed after interventions regarding the perception of control, self-perception, positive attitude towards the disability and increased satisfaction with life in SCI care. Depression and anxiety, which could be achieved outcomes of psychological training, were improved in seven studies.

Group coping strategies and cognitive behavioral skills enhancement were mainly focused in the interventional studies. Results specify a positive trend of betterment in quality of life, participation in community activities and functional independence (Table 3).

\section{DISCUSSION}

The importance of intervention in SCI is directed towards improvements in long-term outcomes. Early intervention is the key to better rehabilitation outcomes in patients with SCI. Some of the conventional rehabilitation strategies used are range of motion and strengthening exercises, bed mobility and transfer exercises. ${ }^{10,11}$ Patients with SCI experience increased emotional distress, pain and dependency which consequently affect their functional dependence and quality of life, therefore 
Psychological issues should be addressed and need special attention. ${ }^{12,13}$

This review explores the psychological interventions and their effects on rehabilitation outcomes in patients with SCI. Some short-term positive results of these interventions were seen regarding cognitive functioning and emotional outcomes. Psychological intervention helps improve emotional distress and post-traumatic stress in these patients. Worsening of clinical symptoms like depression, anxiety and stress besides other mood disorders have been reported after discontinuation of psychological treatment especially patients receiving Cognitive Behavior Therapy (CBT). ${ }^{14}, 15$ The fairly diverse approaches adopted within the interventions make it inconvenient to clarify their therapeutic mechanisms. However, CBT was adopted in most studies. Additionally, cognitive reconstructing, coping, relaxation techniques and problem-solving skills were mainly opted techniques resulting in positive rehabilitation outcomes and appeared to be a promising intervention strategy. Mostly outcomes addressed psychosocial variables comprising cognitive appraisal, coping, mood status or other adaptations such as life satisfaction and quality of life. Patients' independence in daily living and other physical health outcomes are also valid to assess the effects of psychosocial interventions and results signified positive and strong impact on the outcomes. Strong relationship was found between appraisals, coping strategies, mood and functional outcomes. ${ }^{5,16}$

Quality of life can be assessed by measuring psychological well-being. Factors that contribute to psychological well-being include greater leisure satisfaction, positive self-perception and adjustment, increase social interaction, increased satisfaction with social support and spiritual coping. These interventions specifically improved quality of life. Perceived loss of physical functioning is more threatening than severity of injury and needs psychotherapy to guide the patients and help them to overcome the barriers. Cognitive reconstruction techniques may help in reshaping inaccurate loss of perception and improvement in psychological well-being. ${ }^{17}$ Adequate adaptation, coping and adjustment with SCI are supposed to result in mild stress reactions and better mental health, life satisfaction, quality of life and community participation.

We compare our studies with the effects of psychological interventions on rehabilitation outcomes in stroke patients. Different psychological issues like anxiety, depression and insomnia are very common after stroke. These factors negatively affect rehabilitation outcomes in stroke patients, therefore psychology consultations were central in helping optimize their functional outcomes and rehabilitation. Mental practice used as an intervention had positive effects on arm functions in stroke patients.
Single case study findings indicate that it also helps in the improvement of leg function. ${ }^{18}$ Mental practice also enhances patient's physical performance, selfdetermination and empowerment. ${ }^{19}$ The study proposed that the mental practice may be a useful measure and tool as an adjunct to physiotherapy after stroke. ${ }^{20}$ Impaired cognitive status of elderly stroke patients had negative effects on rehabilitation outcomes. ${ }^{21}$ Mental practice in the treatment group showed a significant increase in daily arm functions and a reduction in affected arm impairment. ${ }^{22}$ These findings suggest that psychological interventions had also positive effects on rehabilitation outcomes in stroke patients as found in people with $\mathrm{SCI}^{23}$

\section{CONCLUSION}

This review adds to currently present literature that the use of psychological or psychosocial interventions influence positively various rehabilitation outcomes in SCI patients; increasing their life satisfaction and quality of life. Among other psychological interventions, CBT was adequately found efficacious in improving coping and adjustments following SCI.

\section{LIMITATIONS}

Most studies addressed different components of CBT such as psycho-education, relaxation techniques, cognitive reconstruction, increased behavioral activation and training. Because we did not conduct statistical analysis, consequently, it was difficult to evaluate which intervention or combination was more effective in patients with SCI. Loss of follow-up was a major drawback in most of the included studies, hence the longterm effects of the interventions given were not evident. Moreover, the effects of social factors in the rehabilitation phase were not addressed in most of the studies and further research is required to relate study outcomes to the targeted social intervention. We recommend further research in this area using an extended range of psychological measures and functional evaluation tools.

\section{REFERENCES}

1. Craig A, Tran Y, Middleton J. Psychological morbidity and spinal cord injury: a systematic review. Spinal cord. 2009;47(2):108-114.

2. Hammell KW. Psychological and sociological theories concerning adjustment to traumatic spinal cord injury: the implications for rehabilitation. Spinal Cord. 1992;30(5):317-326.

3. Post M, Van Leeuwen C. Psychosocial issues in spinal cord injury: a review. Spinal cord.

2012;50(5):382-389.

4. Chevalier Z, Kennedy P, Sherlock O. Spinal cord injury, coping and psychological adjustment: a literature review. Spinal cord. 2009;47(11):778-782. 5. Kennedy P, Lude P, Elfström ML, Smithson EF. Psychological contributions to functional independence: a longitudinal investigation of spinal 
cord injury rehabilitation. Archives of Physical Medicine and Rehabilitation. 2011;92(4):597-602.

6. Galvin L, Godfrey H. The impact of coping on emotional adjustment to spinal cord injury (SCI): review of the literature and application of a stress appraisal and coping formulation. Spinal cord. 2001;39(12):615-627.

7. North N. The psychological effects of spinal cord injury: a review. Spinal cord. 1999;37(10):671679.

8. Mehta S, Orenczuk S, Hansen KT, et al. An evidence-based review of the effectiveness of cognitive behavioral therapy for psychosocial issues post-spinal cord injury. Rehabilitation Psychology. 2011;56(1):15. 9. Huston T, Gassaway J, Wilson C, Gordon S, Koval J, Schwebel A. Psychology treatment time during inpatient spinal cord injury rehabilitation. The Journal of Spinal Cord Medicine. 2011;34(2):196-204.

10. Hachem LD, Ahuja CS, Fehlings MG. Assessment and management of acute spinal cord injury: From point of injury to rehabilitation. The journal of spinal cord medicine. 2017;40(6):665-675. 11. Craig AR, Hancock K, Dickson H, Chang E. Long-term psychological outcomes in spinal cord injured persons: results of a controlled trial using cognitive behavior therapy. Archives of Physical Medicine and Rehabilitation. 1997;78(1):33-38.

12. Fann JR, Bombardier CH, Richards JS, et al. Depression after spinal cord injury: comorbidities, mental health service use, and adequacy of treatment. Archives of Physical medicine and Rehabilitation. 2011;92(3):352-360.

13. Kemp BJ, Kahan JS, Krause JS, Adkins RH, Nava GN. Treatment of major depression in individuals with spinal cord injury. The journal of spinal cord medicine. 2004;27(1):22-28.

14. Dorstyn D, Mathias J, Denson L.

Psychological intervention during spinal rehabilitation: a preliminary study. Spinal Cord. 2010;48(10):756-761.
15. Craig A, Hancock K, Chang E, Dickson H.

The effectiveness of group psychological intervention in enhancing perceptions of control following spinal cord injury. Australian \& New Zealand Journal of Psychiatry. 1998;32(1):112-118.

16. Heinemann AW, Wilson CS, Huston T, et al. Relationship of psychology inpatient rehabilitation services and patient characteristics to outcomes following spinal cord injury: The SCIRehab Project. The journal of spinal cord medicine. 2012;35(6):578592.

17. deRoon-Cassini TA, de St Aubin E, Valvano A, Hastings J, Horn P. Psychological well-being after spinal cord injury: perception of loss and meaning making. Rehabilitation psychology. 2009;54(3):306. 18. Braun SM, Beurskens AJ, Borm PJ, Schack T, Wade DT. The effects of mental practice in stroke rehabilitation: a systematic review. Archives of physical medicine and rehabilitation. 2006;87(6):842-852.

19. Braun S, Kleynen M, Schols J, Schack T, Beurskens A, Wade D. Using mental practice in stroke rehabilitation: a framework. Clinical rehabilitation. 2008;22(7):579-591.

20. Crosbie JH, McDonough SM, Gilmore DH, Wiggam MI. The adjunctive role of mental practice in the rehabilitation of the upper limb after hemiplegic stroke: a pilot studya. Clinical rehabilitation. 2004;18(1):60-68.

21. Heruti RJ, Lusky A, Dankner R, et al. Rehabilitation outcome of elderly patients after a first stroke: effect of cognitive status at admission on the functional outcome. Archives of physical medicine and rehabilitation. 2002;83(6):742-749.

22. Page SJ, Levine P, Leonard A. Mental practice in chronic stroke: results of a randomized, placebocontrolled trial. Stroke. 2007;38(4):1293-1297.

23. Perna R, Harik L. The role of rehabilitation psychology in stroke care described through case examples. NeuroRehabilitation. 2020;(Preprint):1-10. 


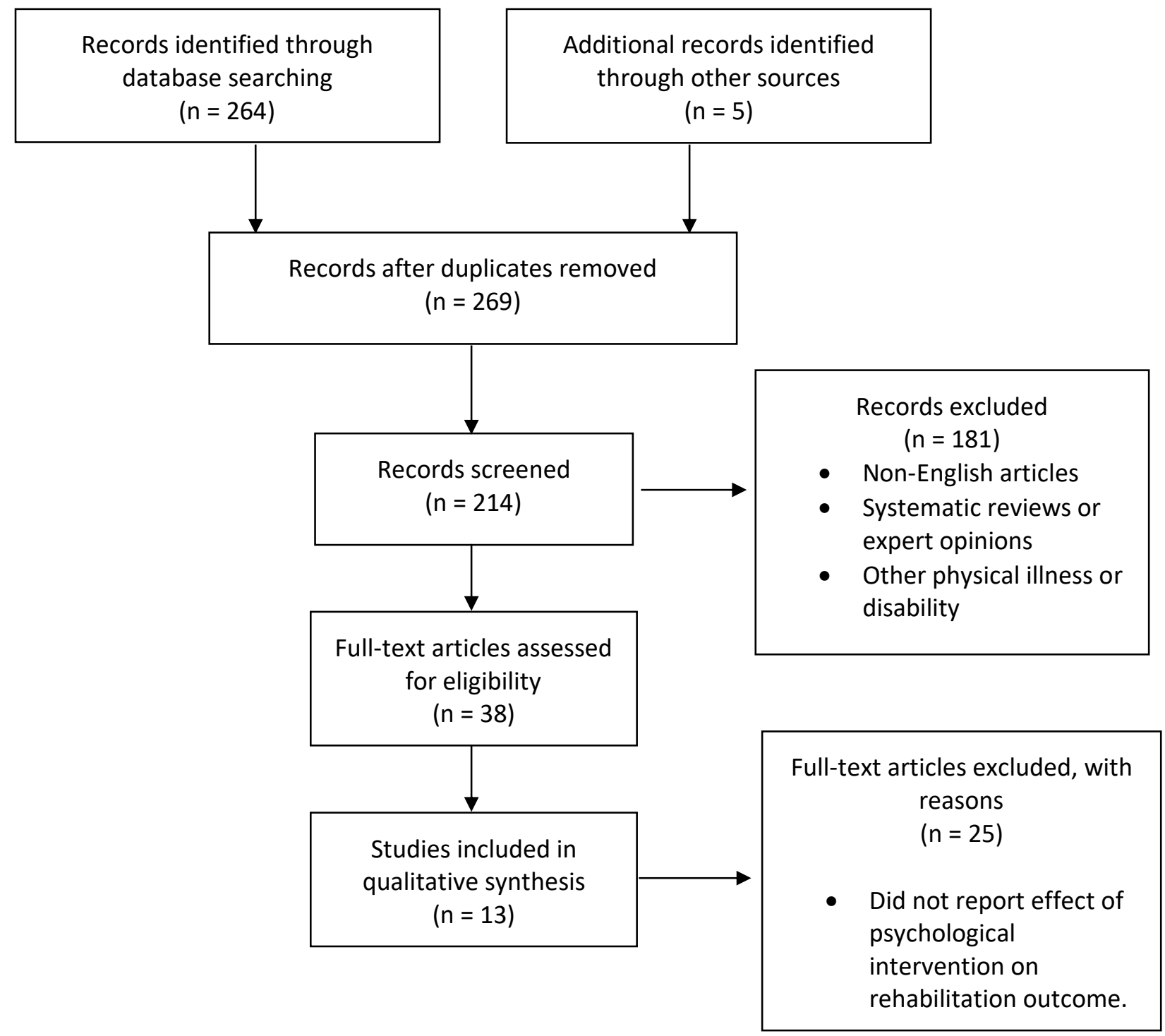

FIGURE 1: PRISMA FLOW CHART 
Table 1: Methodological Quality of the observational studies assessed on NIH quality assessment tool for observational studies

\begin{tabular}{|c|c|c|c|c|c|c|c|c|c|c|c|c|c|c|c|}
\hline & 1 & 2 & 3 & 4 & 5 & 6 & 7 & 8 & 9 & 10 & 11 & 12 & 13 & 14 & TOTAL \\
\hline Craig et al. 1997 & yes & yes & yes & yes & no & NR & NR & NR & no & NR & no & NR & NR & NR & 4 \\
\hline Craig et al. 1998 & yes & yes & yes & yes & yes & NR & NR & NR & no & NR & yes & NR & NR & NR & 6 \\
\hline Kemp et al. 2004 & yes & yes & yes & yes & yes & NR & NR & NR & no & NR & yes & NR & NR & NR & 6 \\
\hline Perry et al. 2008 & yes & yes & no & yes & no & NR & NR & NR & no & NR & no & NR & NR & NR & 3 \\
\hline Kennedy et al. 2008 & yes & yes & yes & no & yes & NR & NR & NR & yes & NR & yes & NR & NR & NR & 6 \\
\hline Dorstyn et al. 2009 & no & no & no & yes & yes & NR & NR & NR & yes & NR & yes & NR & NR & NR & 4 \\
\hline Hastings et al. 2009 & yes & yes & NA & yes & yes & NR & NR & NR & yes & NR & yes & NR & NR & NR & 4 \\
\hline Heinemann et al. 2009 & yes & yes & yes & yes & yes & NR & NR & NR & yes & NR & yes & NR & NR & NR & 7 \\
\hline Kennedy et al. 2011 & yes & yes & yes & yes & yes & NR & NR & NR & no & NR & no & NR & NR & NR & 5 \\
\hline Huston et al. 2011 & yes & yes & no & yes & no & NR & NR & NR & no & NR & yes & NR & NR & NR & 4 \\
\hline Wang et al. 2017 & yes & yes & no & no & yes & NR & NR & NR & yes & NR & yes & NR & NR & NR & 5 \\
\hline
\end{tabular}

Table 2: Methodological Quality of the interventional studies assessed on PEDro scale

\begin{tabular}{|c|c|c|c|c|c|c|c|c|c|c|c|c|}
\hline Study & Q1 & Q2 & Q3 & Q4 & Q5 & Q6 & Q7 & $\mathrm{Q} 8$ & Q9 & Q10 & Q11 & Total \\
\hline Duchnick et al. 2009 & NA & Yes & No & Yes & No & No & No & Yes & No & Yes & Yes & 5 \\
\hline Schulz et al. 2009 & NA & Yes & Yes & Yes & No & No & Yes & Yes & No & Yes & No & 6 \\
\hline
\end{tabular}

Table 3: Summary of the studies included in this review

\begin{tabular}{|c|c|c|c|c|c|}
\hline $\begin{array}{l}\text { Study/country/Study } \\
\text { design/quality }\end{array}$ & $\begin{array}{l}\text { Target } \\
\text { population }\end{array}$ & $\begin{array}{l}\text { Psychological } \\
\text { interventions }\end{array}$ & $\begin{array}{l}\text { Outcome } \\
\text { measures }\end{array}$ & Rehabilitation outcomes & Additional findings \\
\hline $\begin{array}{l}\text { Craig et al. (1997)/ Australia/ } \\
\text { Observational/4 }\end{array}$ & $\begin{array}{l}\text { Control group }=41 \text {, } \\
\text { Treatment } \\
\text { group }=28 \text {, } \\
\text { mild to moderate } \\
\text { depression and } \\
\text { anxiety. }\end{array}$ & $\begin{array}{l}\text { CBT given to } \\
\text { treatment group for } \\
\text { depression, anxiety } \\
\text { and self-esteem }\end{array}$ & $\begin{array}{l}\text { STAIC, BDI, } \\
\text { Rosenberg self- } \\
\text { esteem scale }\end{array}$ & $\begin{array}{l}\text { Significant difference in control group having higher } \\
\text { level of depressive mood in long term than the } \\
\text { treatment group were reported. Significant difference } \\
\text { was found in anxiety showing decreased score over } \\
\text { time for those who were more anxious before } \\
\text { treatment. }\end{array}$ & $\begin{array}{l}\text { The number of subjects } \\
\text { showing low self-esteem } \\
\text { was } 3 \text { in treatment and } 14 \\
\text { in control group after } 12 \\
\text { months follow up }\end{array}$ \\
\hline $\begin{array}{l}\text { Craig et al. (1998)/ Australia } \\
\text { / Observational } / 6\end{array}$ & $\begin{array}{l}\text { control=31, } \quad \mathrm{N} \\
\text { treatment }=27, \\
\text { mean age }=31 \\
\text { years. }\end{array}$ & $\begin{array}{l}\text { Tx group: CBT } \\
\text { CT group: traditional } \\
\text { rehabilitation. }\end{array}$ & BDI, LCB & $\begin{array}{l}\text { No significant differences were seen in LCB scores } \\
\text { within groups. Decreased depressive symptoms were } \\
\text { correlated with participant's locus of control. }\end{array}$ & $\begin{array}{l}\text { Participants with external } \\
\text { locus of control at } \\
\text { baseline, showed } \\
\text { Improvement in LCB } \\
\text { scores. }\end{array}$ \\
\hline
\end{tabular}




\begin{tabular}{|c|c|c|c|c|c|}
\hline $\begin{array}{l}\text { Kemp et al. (2004) /USA / } \\
\text { Observational } / 6\end{array}$ & $\begin{array}{l}\text { Treatment }=28, \\
\text { Control }=15 \text {, mean } \\
\text { age }=42 \text { years, } \\
\text { treatment time }=6 \\
\text { months. }\end{array}$ & $\begin{array}{l}\text { Individual } \\
\text { psychotherapy }\end{array}$ & LSS, CAC & $\begin{array}{l}\text { TX group: significant decrease in mean depression } \\
\text { scores. Community participation increased in the } \\
\text { treatment period along with life satisfaction over } 24 \\
\text { months. Control group: no change in depression scores }\end{array}$ & $\begin{array}{l}\text { Considerable level of } \\
\text { depression found at the } \\
\text { end of } 6 \text { months. }\end{array}$ \\
\hline $\begin{array}{l}\text { Perry et al. (2008)/ Australia/ } \\
\text { Observational /3 }\end{array}$ & $\begin{array}{l}\text { Treatment }=19, \\
\text { Usual care pts } \\
=17 \text {, chronic pain. }\end{array}$ & $\begin{array}{l}\text { group Pain } \\
\text { Management Program }\end{array}$ & $\begin{array}{l}\text { PRSS, PSEQ, } \\
\text { HADS, MSES }\end{array}$ & $\begin{array}{l}\text { PMP group signifies improvements in mood \& life } \\
\text { interference due to pain compared to usual care group, } \\
\text { additionally; improvements over time in anxiety and } \\
\text { pain catastrophizing were shown. }\end{array}$ & $\begin{array}{l}\text { Cognitive-behavioural } \\
\text { PMPs recommended to } \\
\text { SCI-related chronic pain }\end{array}$ \\
\hline $\begin{array}{l}\text { Kennedy et al. (2008)/ UK/ } \\
\text { Observational } / 6\end{array}$ & $\begin{array}{l}\text { MHD group }=14, \\
\text { Non } \quad \text { MHD } \\
\text { group=14, Mean } \\
\text { Age } 34 \text { years, }\end{array}$ & $\begin{array}{l}\text { MHD group receives } \\
\text { psychological } \\
\text { intervention and } \\
\text { conventional } \\
\text { rehabilitation }\end{array}$ & NAC & $\begin{array}{l}\text { No significant difference was found between the } \\
\text { groups regarding rehabilitation outcomes. Increased } \\
\text { outcomes in MHD group were directly related with } \\
\text { early psychological intervention provided. }\end{array}$ & NA \\
\hline $\begin{array}{l}\text { Dorstyn et al. (2009)/ } \\
\text { Australia/ } \\
\text { /Non RCT/4 }\end{array}$ & $\begin{array}{l}\text { treatment } \\
\text { group }=13, \text { Control } \\
\text { group }=11 .\end{array}$ & $\begin{array}{l}\text { Group } \quad \text { CBT for } \\
\text { anxiety, } \quad \text { depression } \\
\text { and stress }\end{array}$ & DASS-21, FIM & $\begin{array}{l}\text { CBT in treatment group showed significant } \\
\text { improvement in anxiety, depression and stress } \\
\text { syndrome after } 12 \text { weeks. FIM was similar for both } \\
\text { treatment and control groups. }\end{array}$ & $\begin{array}{l}\text { Clinical improvement in } \\
\text { symptoms of anxiety and } \\
\text { stress were observed in } \\
\text { treatment group }\end{array}$ \\
\hline $\begin{array}{l}\text { Duchnick et al. (2009)/ south } \\
\text { Florida/ Interventional/ } \\
\text { RCT/4 }\end{array}$ & $\begin{array}{l}\mathrm{N} 1=20, \quad \mathrm{~N} 2=20, \\
\text { mean age } 52.6 \\
\text { years }\end{array}$ & $\begin{array}{l}\mathrm{N} 1=\text { coping } \\
\text { effectiveness } \\
\mathrm{N} 2=\text { supportive group } \\
\text { therapy }\end{array}$ & $\begin{array}{l}\text { SAI, CESD, } \\
\text { ADS-R }\end{array}$ & $\begin{array}{l}\text { Lower depression score and better adjustment to } \\
\text { disability. Decrease in depression and anxiety was seen } \\
\text { at discharge and follow up screening for CET and SGT. }\end{array}$ & $\begin{array}{l}\text { CET could be more } \\
\text { efficient for acute } \\
\text { rehabilitation. }\end{array}$ \\
\hline $\begin{array}{l}\text { Hasting et al. (2009)/ USA / } \\
\text { Observational /4 }\end{array}$ & $\begin{array}{l}\mathrm{N}=79, \quad \text { chronic } \\
\text { injury }\end{array}$ & $\begin{array}{l}\text { CBT, } \\
\text { psychotherapeutic } \\
\text { intervention focused } \\
\text { on positive self- } \\
\text { perception }\end{array}$ & $\begin{array}{l}\text { SF-36, sense of } \\
\text { well-being } \\
\text { inventory, } \\
\text { purpose in life } \\
\text { scale. }\end{array}$ & $\begin{array}{l}\text { Increased sense of psychological well-being, purpose } \\
\text { in life after the injury and a positive attitude towards } \\
\text { the disability. }\end{array}$ & $\begin{array}{l}\text { Perceived loss of physical } \\
\text { abilities and generation of } \\
\text { purpose in life are related } \\
\text { to positive adaptation }\end{array}$ \\
\hline $\begin{array}{l}\text { Schulz et al. (2009)/ USA/ } \\
\text { Interventional } / 7\end{array}$ & $\begin{array}{l}\text { dual target }=114, \\
\text { caregiver }=112, \\
\text { control } \\
\text { group }=120, \text { mean } \\
\text { age }=50-54 .\end{array}$ & $\begin{array}{l}\text { dual target= cognitive } \\
\text { and behavioural skills, } \\
\text { caregiver only= } \\
\text { knowledge and skills } \\
\text { control group= written } \\
\text { information on SCI }\end{array}$ & $\begin{array}{l}\text { CESD, brief } \\
\text { version of } \\
\text { caregiver burden } \\
\text { interview, self- } \\
\text { care problems }\end{array}$ & $\begin{array}{l}\text { Marked improvements in CESD scoring was shown in } \\
\text { the dual treatment group in comparison with the } \\
\text { control group and caregiver only. Dual treatment group } \\
\text { had better QOL compared to control and caregiver } \\
\text { only. }\end{array}$ & $\begin{array}{l}\text { Patients were not followed } \\
\text { for long period of time. }\end{array}$ \\
\hline
\end{tabular}




\begin{tabular}{|c|c|c|c|c|c|}
\hline $\begin{array}{l}\text { Heinemann et al. (2009)/ } \\
\text { USA/ Observational /7 }\end{array}$ & $\begin{array}{l}\mathrm{N}=1032, \quad \text { Age }=12 \\
\text { years or older, }\end{array}$ & $\begin{array}{l}\text { Individual and family } \\
\text { psychological sessions } \\
\text { also consultation with } \\
\text { rehabilitation team }\end{array}$ & $\begin{array}{l}\text { FIM, CHART, } \\
\text { SWL, patient } \\
\text { health } \\
\text { questionnaire. }\end{array}$ & $\begin{array}{l}\text { Patients receiving early psycho-educational } \\
\text { intervention results had better functional outcome, } \\
\text { absence of pressure ulcers at } 1 \text { year, discharge to home } \\
\text { and home residence at } 1 \text { year. Psychotherapeutic } \\
\text { sessions focusing on emotions were related with poor } \\
\text { function at discharge, less community mobility, less } \\
\text { functional independence, lower satisfaction level and } \\
\text { presence of pressure ulcers at } 1 \text { year. }\end{array}$ & NA \\
\hline $\begin{array}{l}\text { Kennedy et al. (2011)/ } \\
\text { England/Germany and } \\
\text { Ireland/ Observational } / 5\end{array}$ & $\begin{array}{l}\mathrm{N}=127 \\
\mathrm{M}=101 / \mathrm{F}=26 \\
\text { mean age }=39.3 \\
\text { years }\end{array}$ & 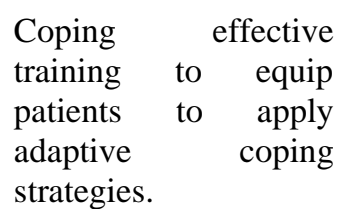 & $\begin{array}{l}\text { FIM, COPE, SCL } \\
\text { CSQ }\end{array}$ & $\begin{array}{l}\text { Positive appraisals of disability and functional coping } \\
\text { strategies (social reliance and behavioural } \\
\text { engagement) were linked to less depression in SCI, } \\
\text { resulting in positive impact on functional } \\
\text { achievements. }\end{array}$ & $\begin{array}{l}\text { Psychological support } \\
\text { may lead to significant } \\
\text { improvement in QOL }\end{array}$ \\
\hline $\begin{array}{l}\text { Huston et al. (2011)/ USA/ } \\
\text { Observational /4 }\end{array}$ & $\begin{array}{l}\mathrm{N}=600, \quad \text { Age }=12 \\
\text { years or older. }\end{array}$ & $\begin{array}{l}\text { Psychotherapeutic } \\
\text { intervention, psycho- } \\
\text { educational } \\
\text { intervention, Class led } \\
\text { by psychologist } \\
\text { consultation, } \\
\text { Interdisciplinary } \\
\text { conferencing on behalf } \\
\text { of patients }\end{array}$ & $\begin{array}{l}\text { ISNCSCI, AIS, } \\
\text { CSI, FIM, BSI- } \\
18\end{array}$ & $\begin{array}{l}\text { Anxiety and depression scores were co-related with } \\
\text { more psycho-educational than psychotherapeutic } \\
\text { Intervention for patients in two tetraplegic injury } \\
\text { group. Depression scores in pts with paraplegia were } \\
\text { correlated with greater amount of time spent in any } \\
\text { psychological intervention. No correlation between } \\
\text { time spent in psychological intervention and BSI score } \\
\text { for patients in ASIA D. }\end{array}$ & $\begin{array}{l}\text { The variation observed in } \\
\text { psychological intervention } \\
\text { was not explained by } \\
\text { patients and injury } \\
\text { characteristics }\end{array}$ \\
\hline $\begin{array}{l}\text { Wang et al. (2017)/ China/ } \\
\text { Observational /5 }\end{array}$ & $\begin{array}{l}\mathrm{N}=300, \text { Mean age } \\
(45.81+/-12.89)\end{array}$ & $\begin{array}{lr}\text { Psychological } & \\
\text { intervention } & \text { for } \\
\text { depression, } & \text { anxiety } \\
\text { and PTSD }\end{array}$ & $\begin{array}{l}\text { IES-R, HADS, } \\
\text { CD-RISC, PTGI }\end{array}$ & $\begin{array}{l}\text { Resilience and PTG were measured in which } 32 \% \\
\text { reported good resilience and } 51 \% \text { showed moderate to } \\
\text { high level of PTG. Increased resilience and PTG } \\
\text { showed better rehabilitation outcomes. }\end{array}$ & $\begin{array}{l}\text { Due to high prevalence of } \\
\text { psychological morbidities } \\
\text { in SCI, they should be } \\
\text { provided with early } \\
\text { intervention } \quad \text { in } \\
\text { rehabilitation. }\end{array}$ \\
\hline \multicolumn{6}{|c|}{$\begin{array}{l}\text { BDI beck depression inventory, LCB locus of control behaviour scale, FIM functional independence measure, DASS } 21 \text { depression anxiety and stress scale, CHART Craig handicap } \\
\text { assessment and reporting technique, SWL satisfaction with life scale, ISNCSCI international standard of neurological classification of spinal cord injury, AIS American spinal cord } \\
\text { injury association impairment scale, CSI comprehensive severity scale, BSI brief symptom inventory, IES-R impact of event scale-revised, HADS hospital anxiety and depression scale, } \\
\text { CD-RISC Connor Davidson resilience scale, PTGI post traumatic growth inventory, NAC need assessment checklist, STAIC Spielberger state trait anxiety scale, LSS life satisfaction } \\
\text { scale, CAC community activities checklist, PRRSS pain related self-statement, PSEQ pain self-efficacy questionnaire, MSES mooring self-efficacy scale, SAI state anxiety inventory, } \\
\text { CESD centre of epidemiologic studies depression scale, ADS-R adaptation to disability scale revised, QOL Quality of life. }\end{array}$} \\
\hline
\end{tabular}

